\title{
The Development of Tax Law Application Formula in Indonesia from IRAC into IREAC
}

\author{
Agus Suharsono ${ }^{*}$ and Burhanudin Harahap ${ }^{2}$ \\ ${ }^{1}$ Doctoral students of Law, Faculty of Law Sebelas Maret University, Surakarta, Indonesia and Senior \\ Tax Trainer at BPPK \\ ${ }^{2}$ Faculty of Law, Sebelas Maret University, Surakarta, Indonesia
}

\begin{abstract}
The characteristic and pattern of tax collection system in Indonesia is mutual cooperation (kegotongroyongan) conducted using selfassessment system, in which taxpayer is trusted to calculate, to consider, to pay, and to report its own tax. Having gotten evidence, tax authority will publish tax stipulation for which a legal attempt can be file in the form of objection, appeal or judicial review. The number of tax disputes is substantial, indicating that there is a difference of tax law application, the process of applying law to the fact or concrete event. In addition to syllogism, the application of law can be done using a more comprehensive and practical formula, IRAC/ILAC. This study was a library research on law and book/article using statute, conceptual and analytical approaches. The result showed that many tax stipulations become tax dispute due to the difference of interpretation on law and evidence validation. Viewed from juridical aspect, Laws on Tax General Provisions and Tax Court govern that the key to tax law application in Indonesia is evidence. Thus, the application of Indonesian tax law with IRAC formula can be expanded by adding "evidence" into IREAC: Issues-Rules-Evidence-Application-Conclusion.
\end{abstract}

\section{Introduction}

Indonesia is a constitutional state [1]. Tax and other levies that is compelling in nature for the state necessity is governed with the law [1]. In accordance with the principle of people sovereignty, government may not compel the enactment of provision that is compulsory and material in nature, binding and burdening the people without being approved first by the people through their representatives in Legislative Assembly [2]. The role of tax in Indonesian State Income and Expense Budget (thereafter called APBN) is very dominant, as indicated with the state's income estimated to be IDR 1,894 trillions consisting of IDR 1,618 trillions (85.4\%) coming from tax revenue, IDR 275 trillions (14.5\%) from non-tax and IDR 1 trillion $(0 . \%)$ from grant [3]. Tax is indeed compellable, but the compulsion should be based on the law.

Considering the general elucidation of Tax General Provision Law and its amendment, the characteristic, and pattern of tax collection system in Indonesia is mutual cooperation implemented using self-assessment in which the people are trusted to calculate, to consider

\footnotetext{
*Corresponding author: gusharpramudito@gmail.com
} 
and to report their own tax [4] [5] [6] [7]. Taxpayers should pay and report payable tax according to the provision of taxation law, not relying on the tax stipulation, and when the General Director of Tax gets evidence about the incorrect amount of tax paid, the General Director of Tax will determine the payable tax [7]. Tax Assessment (thereafter called SKP) can be Tax Underpayment Assessment (thereafter called SKPKB), Tax Overpayment Assessment (thereafter called SKPLB), and Nil Tax Assessment (thereafter called SKPN). The tax assessment not paid in the specified period of time will underlie the tax collection [7]. Taxpayers not agreeing with the tax assessment published by Tax General Directorate can file objection to the General Director of Tax [7]. Taxpayers not agreeing with Objection Decision (thereafter called SKK) can file appeal to Tax Court [7] [8]. Those in dispute can file judicial review over the decision of Tax Court to the Supreme Court [8].

The object of tax case is tax assessment; Indonesian taxation system is self-assessment; tax assessment is published when there is a difference of tax calculation between taxpayers and tax authority. To find the meeting point (interface) over the difference, the legal attempt can be taken up to the Supreme Court. In 2016, Tax Court has decided about 16,274 cases, about 1,845 or $18.6 \%$ of which file the judicial review to Supreme Court [9]. About 2,057 cases filed judicial review to State Administration Room consisting of 1,845 (89.69\%) tax cases, and $212(10.31 \%)$ other cases [9]. Many tax cases indicate the large difference of tax law application between taxpayers and tax authority.

The application of law is a process of applying law to concrete fact or event. The application of law in the past often used syllogism, but today syllogism it is considered as too simple. There is a law application formula considered as more comprehensive and practical, IRAC: Issues-Rules-Application-Conclusion or ILAC: Issues-Law-ApplicationConclusion [10]. Law Application is legal reasoning, consisting of two formulas: IRAC: Issue-Rule-Analysis-Conclusion and IRFAC: Issue-Rule-Facts-Analysis-Conclusion [11].

\section{Problem Statement}

This study will discuss "how is the development of IRAC/ILAC/IRFAC law application formula in Indonesian tax law?"

\section{Method}

This study analyzed legal phenomenon because law is a teaching system about the reality that should be prescriptive normative [12] and sociological in nature to result in recommendation [13]. This study's normative characteristic lies on the presence of law analyzed [14]. There are some legal study approaches: statute approach, case approach, historical approach, comparative approach, conceptual approach, philosophical approach, and analytical approach [15] [13] [14] [16]. This study employed: 1) statute approach because it analyzed the tax law, 2) conceptual approach as it used concepts of law application to conduct analysis, and 3) analytical approach as it used tax law and law application concept. Data of research included law source [13] including primary law material consisting of RI's 1945 Constitution (UUD NRI 1945) and taxation law, and secondary law material consisting of books and articles of law [15]. Data was collected using library study method [17] including: finding, investigating, learning, recording, and interpreting [18]. 


\section{Discussion}

\subsection{The Formula of Law Application}

Sidharta, having suggested the perspectives of legal scholars such as Sudikno Mertokusumo, Kenneth J. Vandevelde, and Gr. Van der Brught and D.J.C. Winkelman, concluded that there are six main steps of law application: 1) to identify the facts to result in a structure of case actually believed by the judge as the really occurring case; 2 ) to connect (subsume) the structure of case to the relevant law sources, so that he can determine the legal deed in juridical term (legal term); 3) to select relevant rule of law to find out later the policies underlying those rules, so that a coherent structure (map) of rule is produced; 4) to connect the structure of rule and the structure of case; 5) to look for possible alternative solutions; and 6) to apply the choice over one of alternatives to be formulated later as the final decision [19]. Philipus M. Hardjon and Tatiek Sri Djatmiati saw that there are six steps of law application: collecting the fact, classifying the essence of legal problem, identifying and selecting the relevant law content, finding law related to legal issues, and applying the law [20].

William H. Putman argues that "the commonly used approach to legal analysis involves a four-step process. An acronym commonly used in reference to the analytical process is IRAC: Issue, Rule, Analysis/Application, and Conclusion" [21]. Pamela R. Tepper said that many legal writings using IRAC formula: "Identify the issue involved, Determine the relevant rule of law, Apply the rule of law to the facts of your matter, Reach a conclusion" [22]. This formula seems to be simple and restrictive but "it provides a good guide, especially in the beginning when writing an internal memorandum of law is unfamiliar" [22]. IRAC formula with some varying structures (CREAC, TRAC, etc), according to Amy Vorenberg, is the basis to organize legal document used by most legal writing programs "As a scaffolding tool for students, the IRAC paradigm works well, but do not be wedded to this as the only way to teach students how to organize their analysis" [23]. So IRAC is not the only formula, "instead you can encourage students to think less rigidly and develop a structure that is driven by the specific problem rather than fitting the problem into a rigid structure" [23].

Having graduated from school, according to Gerald Lebovits, there are two types of lawyer: those leaving IRAC and those applying IRAC rigidly "these lawyers have forgotten that law school taught them important and lasting skills," or they have forgotten that IRAC is an important and lasting skill [24]. However, "smart lawyers use IRAC variations to formulate their written arguments" [24]. Terrill Pollman \& Judith M. Stinson suggested that law professors have created rich and varied terminology to describe legal writing and the legal-writing process [24]. James Holland and Julian Webb mentioned that there is a number of models and strategies to address legal issues, one of which used most widely is IRAC, by means of dividing the answer into four elements: 1) Introduce the Issues; 2) Discuss the Rules; 3) Next, Apply the rules to the facts in this scenario; and 4) Finally, Conclude by summarizing your analysis [25].

Considering a review on some literatures, it can be found some acronyms in law application. The result of Terril Pollman \& Judith M. Stinson's study showed that "survey participants listed the following acronyms in response to a variety of survey questions: FHRO, T/R/RE/RA/C, CRAC, IRLAFARC, RREACC, TRAC, FIRAC, TREAC, CRPA, IREAC, RREACC, IRAAAC, BaRaC, and C/RAC [26]. Tracy Turner, building on Terril Pollman \& Judith M. Stinson's study, through literature study found twenty acronyms of law application [27]. Kelly Burton's study found thirty six acronyms of law application [28]. John H Wade also conducted a research on MIRAT and CAGONARM formulas [29]. Considering the four studies, the acronyms of law application can be summarized in Table 1. 
Table 1 Acronym of Law Application

\begin{tabular}{|c|c|c|c|}
\hline No & Acronym & Meaning & Source \\
\hline 1 & BaRAC & $\begin{array}{l}\text { Bold assertion, Rule, Application, } \\
\text { Conclusion }\end{array}$ & $\begin{array}{l}\text { Kelly Burton, } \\
\text { Tracy Turner, } \\
\text { Gerald Lebovits }\end{array}$ \\
\hline 2 & CAGONARM & $\begin{array}{l}\text { Current situation, Alleged problems, Goals } \\
\text { of a good system, Options, Necessary action } \\
\text { to achieve options, Advantages and } \\
\text { disadvantages of each option, } \\
\text { Recommending the least detrimental } \\
\text { alternative, Monitoring and measuring the } \\
\text { effects of the reform }\end{array}$ & $\begin{array}{l}\text { Kelly Burton, } \\
\text { John H Wade }\end{array}$ \\
\hline 3 & CI/REXAC & $\begin{array}{l}\text { Conclusion, Introductory/roadmap (issue } \\
\text { and rule), Explanation, Application, } \\
\text { Conclusion }\end{array}$ & Kelly Burton \\
\hline 4 & CIRAC & $\begin{array}{l}\text { Conclusion, Issue, Rule, Application, } \\
\text { Conclusion }\end{array}$ & $\begin{array}{l}\text { Kelly Burton, } \\
\text { Gerald Lebovits }\end{array}$ \\
\hline 5 & CLEO & Claim, Law, Evaluation, Outcome & Kelly Burton \\
\hline 6 & CRAAAP & $\begin{array}{l}\text { Conclusion, Rule, Authority, Application, } \\
\text { Alternative analysis, Policy }\end{array}$ & Tracy Turner \\
\hline 7 & CRAAP & $\begin{array}{l}\text { Conclusion, Rule, Authority, Application, } \\
\text { Policy }\end{array}$ & Tracy Turner \\
\hline 8 & CRAC & Conclusion, Rule, Application, Conclusion & $\begin{array}{l}\text { Tracy Turner, } \\
\text { Gerald Lebovits }\end{array}$ \\
\hline 9 & CRAFADC & $\begin{array}{l}\text { Conclusion, Rule, Authority, Facts, } \\
\text { Analogize/Distinguish, Conclusion }\end{array}$ & Gerald Lebovits \\
\hline 10 & CRARC & $\begin{array}{l}\text { Conclusion, Rule, Application, Rebuttal and } \\
\text { refutation, Conclusion }\end{array}$ & $\begin{array}{l}\text { Kelly Burton, } \\
\text { Tracy Turner }\end{array}$ \\
\hline 11 & CREAC & $\begin{array}{l}\text { Conclusion, Rule, Explanation of the law, } \\
\text { Application, Conclusion }\end{array}$ & $\begin{array}{l}\text { Kelly Burton, } \\
\text { Gerald Lebovits }\end{array}$ \\
\hline 12 & CREXAC & $\begin{array}{l}\text { Conclusion, Rule(s), Explanation of rule(s), } \\
\text { Application of rule }(s) \text {, Conclusion }\end{array}$ & $\begin{array}{l}\text { Kelly Burton, } \\
\text { Tracy Turner }\end{array}$ \\
\hline 13 & CRuPAC & $\begin{array}{l}\text { Conclusion, main Rule, rule Proof or } \\
\text { explanation, Application of rules, } \\
\text { Conclusion }\end{array}$ & $\begin{array}{l}\text { Kelly Burton, } \\
\text { Tracy Turner, } \\
\text { Gerald Lebovits }\end{array}$ \\
\hline 14 & FIRAC & Facts, Issue, Rule, Analysis, Conclusion & $\begin{array}{l}\text { Kelly Burton, } \\
\text { Gerald Lebovits }\end{array}$ \\
\hline 15 & FORAC & $\begin{array}{l}\text { Facts, Outcome, Rule, Application, } \\
\text { Conclusion }\end{array}$ & Gerald Lebovits \\
\hline 16 & HIRAC & $\begin{array}{l}\text { Heading, issue, rule, application, } \\
\text { conclusion }\end{array}$ & Kelly Burton \\
\hline 17 & IDAR & Issue, Doctrine, Application, and Result & $\begin{array}{l}\text { Kelly Burton, } \\
\text { Gerald Lebovits }\end{array}$ \\
\hline 18 & IGPAC & $\begin{array}{l}\text { Issue, General rule, Precedent, Application } \\
\text { of the rules, Conclusion }\end{array}$ & $\begin{array}{l}\text { Kelly Burton, } \\
\text { Tracy Turner, } \\
\text { Gerald Lebovits }\end{array}$ \\
\hline 19 & ILAC & Issue, Law, Application, Conclusion & $\begin{array}{l}\text { Kelly Burton, } \\
\text { Gerald Lebovits }\end{array}$ \\
\hline 20 & IPAAC & $\begin{array}{l}\text { Issue, principle, authority, application, } \\
\text { conclusion }\end{array}$ & Kelly Burton \\
\hline
\end{tabular}




\begin{tabular}{|c|c|c|c|}
\hline No & Acronym & Meaning & Source \\
\hline 21 & IRAAAPC & $\begin{array}{l}\text { Issue, Rule, Authority synthesis, } \\
\text { Application, Alternative analysis, Policy, } \\
\text { Conclusion }\end{array}$ & $\begin{array}{l}\text { Kelly Burton, } \\
\text { Gerald Lebovits }\end{array}$ \\
\hline 22 & IRAACP & $\begin{array}{l}\text { Issue, Rule, Apply, Apply, Conclusion, } \\
\text { Policy }\end{array}$ & $\begin{array}{l}\text { Kelly Burton, } \\
\text { Tracy Turner }\end{array}$ \\
\hline 23 & IRAAPC & $\begin{array}{l}\text { I:issue, Rule, Authority, Application, } \\
\text { Alternative analysis, Policy, Conclusion. }\end{array}$ & $\begin{array}{l}\text { Kelly Burton, } \\
\text { Tracy Turner }\end{array}$ \\
\hline 24 & IRAC & Issue, rule, application, conclusion & $\begin{array}{l}\text { Kelly Burton, } \\
\text { Tracy Turner }\end{array}$ \\
\hline 25 & IRAC plus & $\begin{array}{l}R: \text { rule overview }+ \text { case illustrations, } \\
\text { A:best fact plus compare to precedent plus } \\
\text { connect to expected result }\end{array}$ & Tracy Turner \\
\hline 26 & $\begin{array}{l}\text { IRAC with } \\
\text { EIP }\end{array}$ & Explanation, Illustration, Policy & Tracy Turner \\
\hline 27 & IRACDD & $\begin{array}{l}\text { Issue, rule, analysis, conclusion, defence, } \\
\text { damages }\end{array}$ & Kelly Burton \\
\hline 28 & IRACEIP & $\begin{array}{l}\text { Issue, rule, application, conclusion, } \\
\text { explanation, illustration and policy }\end{array}$ & Kelly Burton \\
\hline 29 & IRAFT & $\begin{array}{l}\text { Issues, rules, application of rules to the } \\
\text { facts, tentative conclusion }\end{array}$ & Kelly Burton \\
\hline 30 & IREAC & $\begin{array}{l}\text { Issue, Rule, Explanation of rule, } \\
\text { Application, Conclusion }\end{array}$ & $\begin{array}{l}\text { Kelly Burton, } \\
\text { Gerald Lebovits }\end{array}$ \\
\hline 31 & IREXAC & $\begin{array}{l}\text { Issue, Rule, Explanation, Application, } \\
\text { Conclusion }\end{array}$ & $\begin{array}{l}\text { Kelly Burton, } \\
\text { Tracy Turner }\end{array}$ \\
\hline 32 & IRRAAC & $\begin{array}{l}\text { Issue, Rule, Reasoning, Application, } \\
\text { Alternative analysis, Conclusion. }\end{array}$ & Tracy Turner \\
\hline 33 & IRRAC & $\begin{array}{l}\text { Issue, Rule, Reasoning, Application, } \\
\text { Alternative analysis, Conclusion. }\end{array}$ & $\begin{array}{l}\text { Kelly Burton, } \\
\text { Tracy Turner }\end{array}$ \\
\hline 34 & IRREAC & Issue, Rule, Rule, Application, Conclusion & Kelly Burton \\
\hline 35 & ISAACS & $\begin{array}{l}\text { Identify a legal issue from the facts, State } \\
\text { the relevant law and authority for it, Apply } \\
\text { the law to the facts, Come to a conclusion } \\
\text { and repeat the steps above to the next issue, } \\
\text { Synthesise the conclusion }\end{array}$ & Kelly Burton \\
\hline 36 & MIRAC & $\begin{array}{l}\text { Material facts, Issues, Rules, Arguments, } \\
\text { Conclusion }\end{array}$ & Kelly Burton \\
\hline 37 & MIRAT & $\begin{array}{l}\text { Material facts, Issues, Rules, Application, } \\
\text { Tentative Conclusion }\end{array}$ & $\begin{array}{l}\text { Kelly Burton, } \\
\text { Gerald Lebovits, } \\
\text { John H Wade }\end{array}$ \\
\hline 38 & RAFADC & $\begin{array}{l}\text { Rule, Authorities, Facts (of the problem } \\
\text { case), Analogizing and Distinguishing, } \\
\text { Conclusion }\end{array}$ & $\begin{array}{l}\text { Kelly Burton, } \\
\text { Tracy Turner, } \\
\text { Gerald Lebovits }\end{array}$ \\
\hline 39 & TREAC & $\begin{array}{l}\text { Topic sentence that states a conclusion, } \\
\text { Rule, Explanation, Application, Conclusion. }\end{array}$ & $\begin{array}{l}\text { Kelly Burton, } \\
\text { Tracy Turner }\end{array}$ \\
\hline 40 & TREACC & $\begin{array}{l}\text { Topic, Rule, Explanation, Analysis, } \\
\text { Counterarguments, Conclusion }\end{array}$ & $\begin{array}{l}\text { Kelly Burton, } \\
\text { Gerald Lebovits }\end{array}$ \\
\hline 41 & TREAT & $\begin{array}{l}\text { Thesis, Rule, Explanation, Application, } \\
\text { Testatement of thesis }\end{array}$ & $\begin{array}{l}\text { Kelly Burton, } \\
\text { Tracy Turner }\end{array}$ \\
\hline
\end{tabular}




\begin{tabular}{|c|l|l|l|}
\hline No & \multicolumn{1}{|c|}{ Acronym } & \multicolumn{1}{c|}{ Meaning } & \multicolumn{1}{c|}{ Source } \\
\hline 42 & TRIAccC & $\begin{array}{l}\text { Topic, Rule, Issues, Analysis (cases, } \\
\text { conclusion), Conclusion }\end{array}$ & Kelly Burton \\
\hline 43 & TRRAC & Thesis, Rule, Rule, Application, Conclusion & $\begin{array}{l}\text { Kelly Burton, } \\
\text { Tracy Turner, } \\
\text { Gerald Lebovits }\end{array}$ \\
\hline
\end{tabular}

Susie Salmon said, "IRAC works, and it works because it echoes the structure of effective legal reasoning", and then, "most effective legal argument employs deductive reasoning", deductive reasoning will connect the fact of rule to the conclusion, "if all premises are true, then the conclusion must be true. If any premise is flawed, the conclusion is unreliable" [30]. Tracy Turner stated "existing scholarship on the proper organization of legal analysis is dominated by the IRAC paradigm and its numerous spin-offs", but "IRAC needs to be flexible because few legal questions can be evaluated by a single rule paragraph and a single application paragraph". The IRAC paradigm is based on an adaptation of deductive syllogism to legal reasoning" [31]. It can be concluded that IRAC is still effective to be the formula of legal reasoning, but it still needs some development according to situation, types of law and rule existing. IRAC formula can also be applied in finding the tax law in Indonesia, of course, with adaptation and development corresponding to Indonesian situation and law.

\subsection{Tax Law Application and Tax Law Effort in Indonesia}

R. Santoso Brotodihardjo citing Andriani's argument stated that tax collection is divided into three classes: 1) taxpayers determine themselves the amount of payable tax, 2) there is cooperation between Taxpayers and Fiskus (tax authority/administration), and 3) fiskus determines itself the amount of payable tax [32]. Self-assessment system, according to Rochmat Soemitro, has been introduced in Indonesia since August 26, 1967 with the ratification of Law Number 8 of 1967 about the Transformation in Perfecting the Income Tax Collection Procedure in 1944, Wealth Tax in 1932, Incorporation Tax in 1925 [33]. Mardiasmo divided tax collection into three: 1) Official Assessment, authorizing the government (fiskus) to determine the amount of payable tax by Taxpayers, with the following characteristics: authority to determine the amount of tax existing in the fiskus, passive taxpayers, payable tax arising after the release of tax assessment by fiskus; 2) SelfAssessment, authorizing the taxpayers to determine themselves the amount of payable tax, with the following characteristics: authority to determine the amount of tax existing in the fiskus, active taxpayers in calculating, depositing, and reporting themselves the payable tax, no intervention but supervision from the fiskus; and 3) Withholding, authorizing the third party (not fiskus and not corresponding taxpayers) to determine the amount of payable tax by taxpayers [34]. From those scholars' opinion, it can be concluded that there are three tax collection systems: self assessment, official assessment, and with holding tax. Taxation held on in Indonesia since the reform of taxation law in 1983 is self-assessment, defined as calculating, considering (taking into account), paying, and reporting their taxation obligation [4].

Indonesian taxation system authorizes DJP (Tax General Directorate) as the tax authority to publish tax assessment, when the tax reported by the taxpayers is not consistent with the actual condition. Taxpayers not agreeing with the tax assessment can file legal attempt in the form of objection. The number of objections is fluctuating annually: 4,649 in 2011, 3,635 in 2012, 2,888 in 2013, and 747 in 2014 [35]. About 414,246 tax assessments were published in 2015 , to $13,432(3.2 \%)$ of which the objection was filed by taxpayers. In $2016,255,718$ 
tax assessments were published, to $9,570(3.7 \%)$ of which the objection was filed by taxpayers [36].

Taxpayers not satisfied with Objection Decision can file appeal to Tax Court. The number of appeals is 5,114 in 2012; 5,188 in 2013; 728 in 2014, 7,454 in 2015, and 7,060 in 2016 [37]. In 2016, Tax Court decided on 12,852 disputes. Most verdicts granted all o f 5,367 or $41.8 \%$, granted some of 1,346 or $10.5 \%$. It means that $52.3 \%$ of taxpayers' appeals were granted. About 2,878 or $22.4 \%$ of appeals were declined or won by DJP [37].

An ordinary legal attempt (appeal to Supreme Court) cannot be taken to the Tax Court's verdict, but the parties (taxpayers and Tax General Directorate) still can take extraordinary legal attempt in the form of Judicial Review to Supreme Court [8]. The number of application for judicial review by Tax General Directorate is 970 in 2011; 1,097 in 2012; 1,914 in 2013; 2,436 in 2014; 2,964 in 2015 [38]; and 3,310 in 2016 [39]. Meanwhile, the number of application for judicial review by taxpayers is 546 in 2011; 754 in 2012; 856 in 2013; 1,345 in 2014; and 1,219 in 2015 [38]. Most verdicts (1,347 or 92\%) of Judicial Review over tax dispute published by Supreme Court declined the application for Judicial Review. About 884 or $65.5 \%$ of the application for Judicial Review by DJP were declined, while 463 or $34.4 \%$ of taxpayers' application were declined in 2015 [38]. Meanwhile, in 2016 there were 1,643 applications for judicial review by Tax General Directorate and 485 by taxpayers [39]. The process of applying the tax law in Indonesia, if generating tax dispute, should pass through a long way and time to both Tax General Directorate and taxpayers, so that an understandable tax law application formula is required.

\subsection{Evidence as the Key to Tax Law Application in Indonesia}

The emergence of tax dispute between Taxpayers and fiskus, according to Hary Djatmiko, is due to the improved understanding to use right and to fulfill taxation obligation among the taxpayers. In addition, it is also due to different perception and interpretation on taxation law as well as its implementation rule, and the validity of evidence in taxation law implementation [40]. In juridical manner, the provision about the importance of evidence in finding the tax law is included into two laws: Laws on Tax General Provisions and Tax Court. Firstly, the stipulation contained in Law on Tax General Provision is as follows: 1) Article 1 number 25 defines examination as a series of activities to collect and to process data, information, and/or evidence implemented objectively and professionally based on a standard examination to examine the compliance with taxation obligation and/or other objectives in the attempt of implementing the provision of taxation legislation; 2) Article 12 clause (3) governs that when Tax General Director gets evidence that the amount of payable tax is incorrect, Tax General Director will determine the amount of payable tax; 3) Article 13 clause (1) letter a governs that within 5 years after the payable tax period or the end of Tax Period, the part of Tax Year or Tax Year, Tax General Director can publish Tax Underpayment Assessment (SKPKB) considering that the payable tax is not paid or underpaid, based on the result of investigation or other information. The elucidation of Article 13 clause (1) explains that it is intended only to Taxpayers not complying with the formal and/or material obligation, based on the result of investigation or other information. Other information is concrete data obtained or owned by Tax General Director, among others, including the result of tax invoice confirmation and Income Tax reduction evidence [7].

Secondly, the provisions of Tax Court Law are as follows: 1) Article 69 clause (1) governs that evidence can be: a) letter or writing; b) expert's information; c) witnesses' information; d) parties' recognition; and/or e) Judge's knowledge. The judge can attempt to find evidence as much as possible including letter or writing before using other evidence; 2) Article 76 governs that the Judge determines what should be authenticated, authentication burden and authentication assessment, and the legal authentication will need at least two evidences; 3) 
Article 78 governs that the Tax Court's verdict is made based on the result of authentication assessment, and based on the corresponding taxation legislation, and judge's conviction (belief); and 4) Article 84 clause (1) letter f governs that the consideration and assessment is made on each evidence filed and anything occurring in the trial when the dispute is examined [8].

Evidence is the key factor to the application of tax law in Indonesia, so that IRAC law application formula should be added with "evidence" in order to be IREAC: Issues-RulesEvidence-Application-Conclusion. Considering the information shown in Table 1, there have been IREAC: Issue, Rule, Explanation of rule, Application, Conclusion and IRREAC: Issue, Rule, Rule, Application, Conclusion. Although the acronyms are the same, the explanation and the purpose are different.

\subsection{The Development of Tax Law Application Formula in Indonesia From IRAC}

\section{to IREAC}

The application of tax law in Indonesia using IREAC formula can be explained as follows. Firstly, Issues are legal fact, event, deed or condition performed by the subject of law as intended in the law. The way of identifying issues is to find out the provision and elements that should be fulfilled in the legal event, deed or condition [10]. The result of identification can be types of tax disputed. Secondly, Rules, after the issues have been identified, the next step is to identify all of rules related to the concrete legal event occurring, using the following strategies: 1) seeing the table of content of the rule (if any), 2) using index (if any), 3) seeing the words or summary existing in the edge of page, 4) reading book related to the event or in the references referred to in the book, 5) searching in the internet through the sites of state institutions, and 6) looking for database of taxation rule such as TaxBase or Ortax [10].

Thirdly, Evidence, Eddy O.S. Hiariej defines the authentication law as the provisions about the authentication including proof of evidence, exhibit, the way of collecting and obtaining evidence and the way of delivering the evidence to the court and authentication power and authentication burden [41]. Meanwhile, there are four concepts of authentication: 1) relevant; 2) acceptable; 3) obtained using right way; and 4) each of evidences should be evaluated by the judge [41]. William R. Bell divided the evidence into seven categories: 1) direct evidence, the direct evidence according to the fact usually obtained from an individual's testimony seeing the fact directly, 2) circumstantial evidence or indirect evidence, the evidence indirectly pointing to the fact, but capable to refer to the actual event, 3) substitute evidence, the one that should not be authenticated either directly or indirectly pertaining to what has been general knowledge or law knowledge; 4) testimonial evidence, consisting of testimony on fact, argument on testimony, and expert opinion; 5) real evidence or physical evidence, the physical object of something related to legal event; 6) demonstrative evidence, the evidence used to explain the facts by investigator before the court, can use the chart of reconstruction result; 7) documentary evidence, the one including handwriting, letter, photography, transcript of recording, and other written proof of evidence [41].

Achmad Ali and Wiwie Heryani concluded Sir Roland's opinion that evidence has two definitions: the part of reason and conclusion to find out the event becoming certainty and principal of any problem. Evidence is used to shows the fact likely known as proof and also some facts relevant to its event. So, evidence is a tool producing verdict [42]. The objective of evidence, according to Milton C. Jacobs, to achieve the truth and to produce verdict. Evidence is medium of proof, while proof is the result or consequence resulting from real evidence, or in other words "evidence is the medium of proof, proof is the effect of evidence" [42].

Tax Court Law governs the evidence (medium of proof) in tax law application in Indonesia as follows: 1) letter or writing consisting of: a) authentic deed, b) underhand deed, and c) decision or decree published by the authorized official and other letters or writing 
closely related to appeal or Suit; 2) expert's information, someone's opinion given under oath in the trial about what he/she knows according to his experience and knowledge; 3) witnesses' information when the information concerns what is experienced, saw, or heard by the witness; 4) parties' recognition; and 4) judge's knowledge [8].

Information and Electronic Transaction Law governs the expansion of evidence, stating that electronic information and/or electronic document and/or its printed product are legitimate legal evidences [45]. Electronic evidence, according to Efa L. Fakhriah, is electronic information, electronic document and other computer output [43]. Electronic information is a set of electronic data including but not limited to writing, voice, picture, map, design, photograph, electronic data interchange, electronic mail, telegram, telex, telecopy or similar, letter, sign, figure (number), access code, symbol, or perforation processed having meaning or understandable to those capable of understanding them [44]. Electronic document is any electronic information developed, forwarded, sent, received, or stored in analog, digital, electromagnetic, optical or similar form, that can be seen, displayed and/or heard through computer or electronic system, including but not limited to writing, voice, picture, map, design, photograph, electronic data interchange, electronic mail, telegram, telex, telecopy or similar, letter, sign, figure (number), access code, symbol, or perforation processed having meaning or understandable to those capable of understanding them [44]. The provision of taxation governs the electronic evidence as follows: 1) Electronic notification signed with electronic or digital signature [7] [45]; 2) electronic tax invoice or einvoice [46] [47]; and 3) book, recording, and document underlying bookkeeping or recording and other document including the result of data processing from bookkeeping managed electronically or using online application program [7].

Fourthly, Application, is the application of law to issue based on existing evidences [10]. Not all laws formulated in appropriate words that can give answer to practical law case, thereby requiring rechtsvinding or law finding, according to Montesquieu, consisting of three elements: 1) judge as the funnel of law, 2) judge as interpreter of law, and 3) if there is no law, the judge should find it [20]. Rechtsvinding model held on recently derived from J.J.H. Bruggink's opinion constituting law interpretation and reasoning or construction [20]. Law reasoning has two specialties: 1) always started with positive law, not limited to its articles only but also including the principles contained in general elucidation and consideration; and 2) law reasoning relates to the procedural framework including three layers of rational law reasoning: a) logic layer constituting internal part of law reasoning, for example: deduction; b) dialectic layer comparing pros and cons argumentation, despite the possibility of not resulting any conclusion because of equal power; and c) procedural layer (dispute settlement procedure) not only governing debate but the debate also determines the procedure [20]. In law reasoning, according to Pranoto Iskandar and Yudi Junadi, we cannot ignore logic, from syllogism, inductive, deductive to analogical. However, they remind us that reasoning and logic are not more than an aid enabling the reasoner to understand the complicatedness of law application [48]. Fifthly, Conclusion, is to conclude how the law should be applied based on issue and evidence elements existing considering the law finding (application) [10].

\section{Conclusion}

The role of tax in Indonesian Income and Expense Budget revenue is very dominant. Tax collection is compellable, but it should be based on the law as the manifestation of constitutional state. The characteristic and pattern of tax collection system in Indonesia include mutual cooperation (kegotongroyongan) conducted using self-assessment, in which the people are trusted to calculate, to consider and to report their own tax. When the General Director of Tax gets evidence about the incorrect amount of tax paid, the General Director of Tax will publish Tax Assessment. Taxpayers not agreeing with the Tax Assessment can take 
legal attempts such as filing objection to Tax General Director, appeal to Tax Court, or Judicial Review to Supreme Court. The number of tax disputes substantial, indicating that there is a difference of tax law application, the process of applying the law to the fact or concrete event. The law application in the past often used syllogism, but because it is considered as too simple, a more comprehensive and practical formula of law application is then developed, IRAC/ILAC, with forty three variations. Tax dispute occurs due to, among others, the difference of interpretation on law and evidence validity. Viewed from juridical aspect, the Laws on Tax General Provisions and Tax Court governs that the key to tax law application in Indonesia is evidence. Thus, the application of Indonesian tax law using IRAC formula can be developed by adding "evidence" into IREAC: Issues-Rules-EvidenceApplication-Conclusion.

\section{References}

1. The 1945 Constitution of Republic Indonesia

2. A. Fatwa, Potret Konstitusi Pasca Amandemen UUD 1945, (PT Kompas Media Nusantara, Jakarta, 2009)

3. The Law No. 15 year 2017 about State Revenue and Expenditure Budget in Fiscal Year 2018

4. The Law No. 6 year 1983 about General Provisions and Taxation Procedures

5. The Law No. 9 year 1994 about the substitution of The Law No. 6 Tahun 1983 about General Provisions and Taxation Procedures

6. The Law No. 16 year 2000 about second change of The Law No. 6 Tahun 1983 about General Provisions and Taxation Procedures.

7. The Law No. 28 year 2007 about the third change of The Law No. 6 year 1983 General Provisions and Taxation Procedures

8. The Law No. 14 year 2002 about Taxation Court

9. MARI, Laporan Tahunan MARI 2016, Jakarta: Sekretariat MARI, 2017, p. 73.

10. S. Riyanto, Keterampilan Hukum, Panduan untuk Mahasiswa, Akademisi dan Praktisis, (Gadjah Mada University Press, Yogyakarta, 2013)

11. W. Susetio, "kemenkumham," [Online]. Available: http://ditjenpp.kemenkumham.go.id/files/doc/2125_Legal\%20Reasoning_Bp.\%20Was is $\% 20$ Susetio.ppt $\% 20 \% 5$ BCompatibility\%20Mode\%5D.pdf. Accessed in 10 June 2014

12. S. Soekanto, Pengantar Penelitian Hukum (UI-Press, Jakarta, 2015)

13. P. M. Marzuki, Penelitian Hukum, (Kencana Jakarta:, 2010)

14. J. Ibrahim, Teori \& Metodologi Penelitian Hukum Normatif, (Bayumedia, Malang 2012)

15. I. M. P. Diantha, Metodologi Hukum Normatif dalam Justifikasi Teori Hukum, (Prenada Media Group, Jakarta, 2016)

16. Z. Ali, Metode Penelitian Hukum, (Sinar Grafika, Jakarta, 2011)

17. Sugiyono, Memahami Penelitian Kualitatif, (Alfabeta, Bandung 2005)

18. L. J. Moleong, Metodologi Penelitian Kualitatif, (Remaja Rosdakarya, Bandung, 2015)

19. Shidarta, Hukum Penalaran dan Penalaran Hukum, (Genta Publishing, Yogyakarta, 2013)

20. T. S. D. Philipus M. Hadjon, Argumentasi Hukum, (Gadjah Mada University Press, Yogyakarta, 2011) 
21. W. H. Putman, Legal Analysis and Writing, (Delmar Cengage Learning, New York, 2009)

22. P. R. Tepper, Basic Legal Writing for Paralegals, (The McGraw-Hill Companies, New York, 2008)

23. A. Vorenberg, Strategies and Techniques for Teaching Legal Analysis and Writing, (Wolter Kluwer Law \& Business, New Hamphire 2012)

24. G. Lebovits, NYSBA, 82, 6, p. 64, (2010)

25. J. W. James Holland, Learning Legal Rules A Students' Guide to Legal Method and Reasoning, Eighth Edition penyunt., (Oxford University Press, Oxford 2013)

26. J. M. S. Terril Pollman, mlr, 56, 2, p. 262 (2004)

27. T. Turner, JALWD, 9, pp. 357-358, (2012)

28. K. Burton, JLD, 10, 2, p. 60, (2017)

29. J. H. Wade, ler, p. 1, (1990)

30. S. Salmon, IRAC: Still the Best Organizational Solution, (Arizona Attorney, Arizona 2014)

31. T. Turner, jlwi, 20, pp. 233-234, (2015)

32. R. S. Brotodiharjo, Pengantar Ilmu Hukum, (Eresco, Bandung, 1987)

33. R. Soemitro, Asas-dan Dasar Perpajakan 2, (Refika Aditama, Bandung, 1991)

34. Mardiasmo, Perpajakan, (Andi, Yogyakarta, 2003)

35. D. J. Pajak, Laporan Tahunan DJP 2015, Direktorat Jenderal Pajak, Jakarta, 2016.

36. D. J. Pajak, "Laporan Kinerja Direktorat Jenderal Pajak 2016," Direktorat Jenderal Pajak, Jakarta, 2017.

37. SetPP, "Pengadilan Pajak," 2017. [Online]. Available: http://www.setpp.kemenkeu.go.id/statistik. Accessed 11 December 2017

38. S. J. Kemenkeu, "Laporan Tahunan Sekretariat Jenderal Kemenkeu Tahun 2015," Sekretariat Jenderal Kemenkeu, Jakarta, 2016.

39. D. J. Pajak, “Laporan Tahunan 2016,” Direktorat Jenderal Pajak, Jakarta, 2017.

40. H. Djatmiko, Problematika Pelaksanaan Pengadilan Khusus di Inonesia, dalam Hitam Putih Pengadilan Khusus, Jakarta, Komisi Yudisial Republik Indonesia, 2013, p. 387.

41. E. O. Hiariej, Teori \& Hukum Pembuktian, Jakarta: Erlangga, 2012, p. 5.

42. W. H. Achmad Ali, Asas-Asas Hukum Pembuktian Perdata, 3 penyunt., Jakarta: Kencana, 2015, p. 18.

43. E. L. Fakhriah, Bukti Elektronik Dalam Sistem Pembuktian Perdata, (Refika Aditama, Bandung 2017)

44. The Law No. 11 Tahun 2008 tentang Informasi dan Transaksi Elektronik, Jakarta: Kemenhum \& HAM, 2008.

45. Regulation of Financial Ministry No. 243/PMK.03/2014 about Notification Letter,

46. Regulation of Financial Ministry No. 151/PMK.03/2013 about Production and Correction Procedure or Replacement of Tax Invoice

47. Regulation of Taxation General Director No. PER-16/PJ/2014 about about Production and Correction Procedure or Replacement of Electric Tax Invoice

48. Y. J. Pranoto Iskandar, Memahami Hukum Di Indonesia, Sebuah Korelasi antara Politik, Filsafat, dan Globalisasi, (IMR Press, Cianjur 2011) 